\title{
The Treatment of Informal Care-Related Risks as Social Risks: An Analysis of the English Care Policy System
}

\author{
FIONA MORGAN \\ University of Wolverhampton, Institute of Public Health, Social Work and Care, Wulfruna \\ Street, Wolverhampton, WV1 1LY \\ email: F.Morgan@wlv.ac.uk
}

\begin{abstract}
The social risk literature examines the extent to which states have provided social protection against the 'old' social risks of the post-war era and the 'new' social risks affecting post-industrial capitalist states. In this paper the contingency of the provision of informal care to people aged 65 and over is discussed. The paper deconstructs the concept of social risk to determine the characteristics and processes which contribute to states recognising specific contingencies as social risks which require social protection. This conceptualisation is applied to make the case that care-related risks associated with the informal care of older people should be recognised and treated as social risks by states. Data from a qualitative study of the English care policy system provide empirical evidence that informal care-related risks are recognised, but not treated, as social risks in England. The findings reveal informal carers, and the older people they care for, receive inadequate and inconsistent statutory protection against the poverty and welfare risks they face. Furthermore the design and operationalisation of the English care policy system generates risks for care relationships.
\end{abstract}

\section{Introduction}

This paper considers the role of the state in recognising and responding to social risks from a conceptual and empirical perspective. The state is defined here as government, in its role as an active agent which can either recognise contingencies as social risks and implement policies and other forms of social protection to address those recognised risks, or leave the risks privatised to the individual to manage through lack of recognition and government inaction. This paper has three key aims. To present a conceptual analysis of social risk which considers the distinct characteristics which make particular contingencies social risks, and the processes through which contingencies become formally recognised by states as social risks. To use this conceptualisation to make the case that the poverty and welfare risks associated with the informal care of older people are social risks which require state protection. To present the results of a qualitative study of 
the English care policy system conducted in 2012-2013. England was selected as the case study on account of UK devolution leading to substantive differences emerging across the four nations in relation to their social care policies. The study used a policy simulation method to analyse the entitlements of different care relationship types across the care services, cash benefits and employment support care policy domains. The findings reveal informal care-related risks are recognised, but not treated, as social risks in England. In conclusion the implications of the Care Act 2014 reform for informal carers are reflected upon in the context of the wider research findings and policy recommendations are made.

\section{Conceptualising social risk}

Contingencies which are identified in the social risk literature and recognised by states as social risks share the following characteristics. Firstly, the wellbeing of the affected risk-bearer is potentially undermined due to the contingency they are experiencing, such as unemployment, disability, or illness, placing them at risk of financial poverty or welfare loss. Often these dual elements of risk are interlinked, with one contributing to the other. Secondly, social risks are universal in nature. Esping-Andersen (1999) considers their incidence predictable at a societal level due to the degree of regularity with which individuals in a given population are affected by such contingencies during their lifecycle. Thirdly, the incidence of social risks at an individual level is recognised to be unpredictable, although Baldwin (1990) and Esping-Andersen (1999) acknowledge that certain groups face increased vulnerability to experiencing and managing social risks on account of their characteristics relating to gender, class, age and, arguably, ethnicity. Lastly, the literature implies that it is only when a state is deemed to have taken explicit responsibility for protecting citizens against a particular contingency, by undertaking some form of substantive public policy intervention, that it is categorised as a social risk. This element of the conceptualisation of social risk has contributed to the social risk literature being disproportionately focused on analysing the state's role in managing the poverty and welfare risks associated with the sphere of paid employment, a limitation which has been noted in other critiques (Jenson, 1997; Hacker, 2004). For example, the literature discusses the 'old' social risks recognised during the welfare state formation period, including short-term unemployment, sickness, invalidity, and life-cycle risks relating to old age poverty (Baldwin, 1990; Huber and Stephens, 2006; Bonoli, 2007). It also examines the 'new' social risks emerging out of the post-industrial changes affecting advanced capitalist societies - in particular, precarious employment, working poverty, long-term unemployment and the reconciliation of work and child care (see for example, Esping-Andersen et al., 2002; Taylor-Gooby, 2004a; Bonoli and Natali, 2012). One further analytical 
distinction used in the social risk literature, which is applied to this analysis, are the concepts of primary and secondary risks. It is noted that states can implement policies which seek to address the 'primary' risk associated with the given contingency. However, the design and implementation of those policies can themselves lead to the production of secondary risks (Kananen et al., 2006). For example, Bonoli (2007) considers how social insurance schemes designed to address 'old' social risks, fail to address the risks of 'new' social risk-bearers with fragmented careers who are better served by non-contributory income transfers. States are also increasingly retrenching existing policy provisions in an attempt to contain public expenditure. This is leading to previously socialised primary risks, such as old age poverty, re-emerging as the state's role is substituted with privatised market or family-based solutions (Ebbinghaus, 2012).

Certain elements of the existing conceptualisation of social risk have undermined the contingencies of informal care and long-term care being fully acknowledged as social risks by the literature. To address this, two key points need to be realised. Firstly, arguably social risks can exist even if they remain unrecognised by states. ${ }^{1}$ Secondly, as previously noted by Baldwin (1990), even where states recognise a contingency as a social risk, different groups of affected risk-bearers may be treated differentially, with social protection being offered to particular groups but not to others. The feminist construction of the publicprivate dichotomy helps to explain the inconsistency in state recognition and treatment of social risks and risk-bearers over time. Fraser (1989) describes how only those contingencies connected to the male sphere of paid employment were deemed suitable for public policy intervention, while those contingencies connected to the private sphere of the household were intentionally excluded from state intervention. Arguably this explains why during the post-war period, with the exception of some Nordic countries (Timonen, 2004), the care-related risks associated with long-term care and informal care remained unrecognised social risks, devoid of state protection, because they were socially constructed as the prerogative of the family to manage. However it is increasingly evident that, during the past few decades of the post-industrial era, states have begun to implement policies to support older people with long-term care needs and their informal carers. In order to explain these policy developments it is necessary to understand the key processes through which social risks and particular groups of risk-bearers become formally recognised by the state as requiring statutory intervention and protection. According to Esping-Andersen (1999) states may react to the inter-related threats of scale and institutional failure when particular contingencies affect growing numbers of citizens and threaten the social or economic wellbeing of society. States may also implement social protection policies because of the social, demographic and economic benefits they can bring, which has undoubtedly incentivised states to recognise childcare 
as a social risk (Daly and Rake, 2003). Moreover, Bonoli (2005) notes how claims-making by affected groups of risk-bearers was critical to 'old' social risks becoming recognised by states, although the claims-making potential of 'new' social risk-bearers is considered to be undermined by their heterogeneity and fragmentation.

\section{Categorising informal care-related risks as social risks}

By applying this two-pronged conceptualisation of social risk to the informal care of older people, it is possible to demonstrate that this contingency features the required characteristics for being categorised as a social risk, and some of the underpinning processes for being recognised as a social risk by states. In terms of characteristics, informal care can incur poverty and welfare risks and, unlike other social risks, involves two inter-related risk-bearers - the person in need of care and the informal carer providing their care - who have the potential to impact on, and exacerbate, one another's risks. Their poverty risks are associated with increased expenditure on items such as care-related household bills (heating, laundry, phone calls etc), transport, medical, care service, and equipment costs (see for example, Carers UK, 2014). Informal carers can also face income-related poverty risks due to their caring role acting as a barrier to labour market participation (see for example, King and Pickard, 2013; Milne et al., 2013). Evandrou and Glaser (2003) note this can create both current and extended life-course poverty risks by affecting earnings levels and career progression, and lead to 'pension penalties' in old age on account of incomplete pension contributions. The welfare risks associated with informal care include injuries and health problems, including psychological issues such as stress, depression and anxiety, which can be exacerbated by the time-poverty risks associated with care-giving and reconciling work and care (Glendinning et al., 2009; Tommis et al., 2009; The NHS Information Centre, 2010). Informal care and long-term care needs are also universal risks, with both contingencies affecting significant numbers of the population in post-industrial societies. In England, for example, the over-65 age group accounted for approximately 18 per cent of the population in 2015 (Office for National Statistics, 2016), with 45 per cent of adults over state pension age reporting having an illness or disability which causes substantial difficulty with daily activities (Family Resources Survey 2014/15 in Department for Work and Pensions, 2016). Pickard et al. (2012) estimated that approximately 65 per cent of older people with disabilities in England receive informal care, with the 2011 Census finding 10.2 per cent of the English population providing at least one hour of informal care per week (Office for National Statistics, 2013a). The informal carer population also consists of an increasingly diverse range of people on account of post-industrial social and demographic changes (Vlachantoni et al., 2013). However, in keeping with 
other social risks, women and low-income groups face greater vulnerability to experiencing care-related risks because they are more likely to experience longterm care needs in old age (Kok et al., 2008; Office for National Statistics, 2014a), and engage in informal care provision (Office for National Statistics, 2013b; 2014b).

The implementation of care polices, which indicate that states are recognising and attempting to address some of the care-related risks associated with informal care and long-term care, is arguably due to the presence of the inter-related threats of scale and institutional failure. During the post-industrial era, demographic, social, and labour market changes including population ageing and advancing medical technology (Kitschelt and Rehm, 2006), increasing female labour market participation and changing family structures and proximity (Daly and Rake, 2003; Pavolini and Ranci, 2008), are extending and intensifying the risks associated with the need for, and provision of, long-term care. According to Huber and Stephens (2006) and Morel (2006), these trends have led to a mismatch of human needs and human resources, because families often lack the human and financial capacity to manage the complex care needs of older relatives unaided. States, including England, have consequently conceded to provide some support to bolster the institution of the family as a care provider, which Singleton and Fry (2015) argue is partly in a bid to reduce further extended claims on state resources in the context of retrenchment and increasing demand. The extent to which claims-making has contributed to states coming to recognise informal carerelated risks as social risks is disputed. Some academics consider the collective mobilisation of informal carers within political processes is undermined by conflicts of interest between the members of the caring dyad (Morel, 2006); the heterogeneity of the people engaged in informal care (Lloyd, 2006); and the isolation of the caring role itself (Anttonen et al., 2003). However, Barnes (2001), Larkin and Milne (2014) consider the political pressure group activity undertaken by key carers' organisations in the UK to have been instrumental to the development of statutory protection mechanisms for informal carers.

In addition to considering the conceptual case for informal care-related risks being categorised as social risks by the literature, it is also necessary to undertake a comprehensive, empirical analysis of the national care policies being implemented by post industrial welfare states and analyse whether they recognise and treat informal care-related risks as social risks. To what extent do states provide comprehensive social protection to all types of informal carers and older people requiring care through the implementation of care policies which provide risk-bearers with adequate time, money and support? A systematic analysis of the English care policy system was undertaken to assess the statutory protection provided in England to different types of risk-bearers, to address their informal care-related risks. 


\section{Methodology}

The qualitative study used a policy simulation tool to analyse the English care policy system in a systematic and comparative way (see Morgan, 2016 for a full discussion of the study's methodology). Eardley (1996) notes how this method can capture the intended effort made by states to mitigate a range of risks from the perspective of different types of potential policy recipients. Three 'model care relationship matrices' were designed, each incorporating two key elements. Firstly, each matrix listed the range of policy mechanisms available in each care policy domain in England. These included cash benefits and other social security measures which compensate people for the provision of care and the costs incurred in requiring care; employment-related measures, such as flexible working legislation and care leave which facilitate the reconciliation of work and caring roles, and Jobcentre Plus support which assists informal carers to return to the labour market; and local authority care services and funding which provides either direct support to informal carers or replacement care to the adults they care for. Secondly, thirteen vignettes were constructed, each one containing a care relationship featuring an informal carer and an older person in receipt of care, whose configuration of characteristics were informed by national statistical data to promote the salience of the care relationship types with empirical reality. The characteristics included: age; financial circumstances; the level of care provided/required; relational status; marital status; employment status; and whether the caring dyad lived together or separately. The design of the matrices enabled the statutory entitlements of different care relationships to be compared to one another, and examined across policy domains, policy mechanisms, localities and practitioners. Data collection took place during 2012-2013. National government data including legislation, policy regulations and websites were used to determine cash benefit entitlements and statutory employment rights, due to these policies being managed or devised centrally. Two localities were selected to obtain data for the care services and Jobcentre Plus domains because their associated policies are devolved to local areas to implement. There were twenty-six research participants. Semi-structured interviews ${ }^{2}$ with front line practitioners and managers from statutory and thirdsector agencies revealed how practitioner decision-making affects the policy outputs of care relationships. Document analysis and interviews with national government and third-sector policy-makers were used to analyse the national carer strategies.

Findings were generated using two qualitative data analysis processes. Firstly the matrix data, which were obtained through the process of determining the policy entitlements of each care relationship, were analysed qualitatively using an interpretive policy analysis approach (see Yanow, 1996). This approach considers how policy entitlements and policy absences reveal which risk-bearers are awarded the status of legitimate claimants for government action. For 
example, the data revealed the characteristics state policies and practitioners use to determine which types of care relationships and care-related risks warrant statutory protection. Meanwhile, policy gaps, which leave particular groups or care-related risks unprotected, expose how the state does not fully recognise or treat those risks as social risks. Secondly, document and interview data were analysed, using thematic coding techniques to identify patterns and trends within and across policy domains, which looked at how informal carers are treated by institutional structures, processes and actors. This helped to reveal the different ways in which the construction and operationalisation of the English care policy system, and the interactions of actors engaged within it, give rise to the inconsistent treatment of informal carers overall.

\section{Findings and discussion}

\section{The recognition and treatment of informal care-related risks as social risks in England}

Informal care-related risks are formally recognised as social risks in each of the national carer strategies. The strategies, implemented by successive New Labour (Department of Health, 1999; 2008) and Coalition Governments (Department of Health, 2010), explicitly acknowledge informal care as a riskbased activity. Furthermore, the state is recognised to have a key, although not the sole, responsibility to provide support and protection (Department of Health, 2008). Various government departments and agencies are identified as needing to provide a range of public services and support in order to better protect informal carers against the poverty and welfare risks they face. However, the strategies themselves contain no mandatory requirements and are not legally binding, and were consequently described by one thirdsector representative as having 'no teeth'. Furthermore, the ineffectiveness of the national carer strategies, to generate the significant policy changes required to ensure that adequate and consistent social protection is provided to informal carers, is evidenced by the matrix data and the analysis of the institutional structures, processes and actors contained in the English care policy system.

The findings expose how informal care-related risks are not treated as social risks in a number of ways. The English care policy system is ineffectually responding to the primary risks associated with the contingency of informal care. This is demonstrated by the inadequacy, inconsistency and gaps in the statutory support available for different risk-bearers. Consequently, informal carers' care-related risks generally remain either fully or partially privatised rather than socialised. Moreover, the design and operationalisation of the policy system is generating secondary risks for risk-bearers. 


\section{Inconsistent treatment of care relationship types}

A key cause of the unequal treatment of both care-related risks and riskbearers emanates from the variable use of characteristics across the eligibility criteria of policy mechanisms, which results in inconsistent access to statutory protection (Morgan, 2016). Consequently, the care-related risks experienced by some groups of risk-bearers are acknowledged by care policies, while others remain ignored. The differential treatment of three types of informal carers serves to illustrate this point. The key group of informal carers who are recognised by English care policies and practitioners to be eligible to access statutory protection are non-employed carers providing full-time care of at least 35 hours per week. However, the level of support provided by state agencies often leaves even their recognised risks only partially socialised. For example, in the cash benefits domain, this type of informal carer is eligible to access Carer's Allowance. However, the low monetary value assigned to this cash benefit which currently stands at $\mathfrak{E} 62.10$ per week (Gov.uk, 2016), ensures that it remains a symbolic payment rather than actively seeking to address carers' income and expenditure related poverty risks. Meanwhile, in the care services domain these 'full-time' carers were consistently assessed by practitioners to be eligible to receive a carer's assessment, and the older people they care for were considered eligible to receive replacement care services. However, the level of support that could be provided was often considered to be inadequate for effectively protecting full-time informal carers against welfare risks. For example, one practitioner discussing the carer break service provided by their local authority stated:

It's not even 2 hours a week ... unless you kind of use it every fortnight ... But you know that's a break a fortnight it's not much is it?

Another practitioner noted service deficiencies to be exacerbated by local authority budget cuts:

You couldn't go to panel and say I want five days day care for this lady because this daughter's not coping ... in this climate ... we could look at day care perhaps one day per week.

At first glance the English state appears to formally recognise informal carers who reconcile paid employment and caring as risk-bearers who require statutory protection. However, the data reveal that in practice these employed carers are primarily treated by the state as workers rather than informal carers, leaving their care-related risks privatised. For instance, the national carer strategies have assiduously promoted work rather than cash benefits as the key way to 'mitigate some of the negative financial effects of caring' (Department of Health, 1999: 88), and extolled the implementation of care leave and flexible working legislation for effectively supporting informal carers to reconcile their work and caring roles. Closer examination of these statutory provisions, however, reveals them as serving the needs of employees and employers more generally, rather than 
informal carers specifically. For example, any employee has the right to take time off in an emergency when a dependant falls ill, gives birth or is injured, assaulted or dies (HM Government, 1999). Moreover the legislation provides no right to take planned care leave, which is arguably a key requirement for informal carers needing to accompany older relatives to appointments. Neither does it require employers to provide any financial protection to employees who activate this right. Consequently the financial risks of taking any time off work to provide care are privatised. Meanwhile the reform of the flexible working legislation, which extended coverage from parents and some types of informal carers to all employees (Acas, 2014), continues to limit employees to a statutory right to request contract variation (HM Government, 2006; Gov.uk, 2014). Consequently employers retain control over which types of flexible working arrangements, if any, to allow within their organisation, and are legally permitted to refuse an employee's request for eight stipulated business reasons (HM Government, 2011). Informal carers may also require replacement care services to be provided to the person they care for so they can go out to work. When carrying out a carer's assessment, local authorities have a duty (retained under the Care Act 2014) to consider the impact that the caring role might have on a carer's employment needs (HM Government, 2004). However, practitioners noted how managers would often authorise inadequate levels or inappropriate types of support, thereby undermining the ability of informal carers to reconcile their work and caring roles:

The panel still prefer universal [community day] services to be used ... [however] ... if the carer was going to ... work universal services would not give them enough time to do so.

Meanwhile, the cash benefits system does not recognise the income-related poverty risks experienced by employed carers who reduce their working hours to provide care. Despite Carer's Allowance being classed as an income-replacement benefit, currently any informal carers earning above $\mathfrak{E} 110$ per week, or caring for less than 35 hours per week, are excluded from claiming it (Gov.uk, 2016). Moreover, informal carers are only eligible to access Working Tax Credits and associated passported benefits to supplement low earnings if they work at least 30 hours per week. They are therefore treated like other low-income workers. In contrast parents with dependent children are eligible if they work 16 hours or more per week (Child Poverty Action Group, 2012). This anomalous treatment of different types of carers, who arguably experience similar care-related financial and time-poverty risks, illustrates how informal carers' risks are overlooked in the cash benefits system.

The care-related risks experienced by part-time carers who are not in work (defined here as individuals providing 16 hours of care per week) are generally neither recognised nor protected by the English state. In the cash benefits and employment support domains these informal carers are treated as unemployed 
workers. As noted previously, carers providing less than 35 hours of care per week cannot claim Carer's Allowance. For low-income, non-employed carers this exemption increases the likelihood of them having to claim the increasingly punitive Jobseeker's Allowance (JSA), rather than Income Support which protects recipients from having to enter employment. Once in receipt of JSA, part-time carers were noted by Benefits Agency and Jobcentre Plus staff to face similar treatment to all unemployed workers. This includes facing benefit sanctions if they do not comply with the requirements set out in their Jobseeker's Agreement: to attend the Jobcentre Plus office fortnightly; demonstrate that job-seeking forms a significant part of their daily activities; with only limited care-related concessions being awarded to attend a job interview with 48 hours notice; and commence a job with one week's notice. Furthermore, the support provided by Jobcentre Plus (JCP) to facilitate re-entry into the labour market does not cater for the specific needs of informal carers. For example, the Work Preparation Support Programme for Lone Parents, Partners and Carers essentially acts as a portal to the generic employment support available to all unemployed individuals. Consequently one JCP practitioner noted that employability training courses were not geared to accommodate the needs of those with caring responsibilities:

The hours that they are expected to be at that opportunity is not very compatible for carers so it can be tricky for them to access that sort of thing.

Meanwhile in the care services domain, part-time carers were treated inconsistently within, as well as across, localities in being considered eligible to access carer's assessments and carer support services. This was because, prior to the implementation of the Care Act 2014, local authorities only had a duty to offer a carer's assessment if the carer was providing or intending to provide 'a substantial amount of care on a regular basis' (HM Government, 1995: 1), a phrase which was subject to divergent interpretations across localities and practitioners (see Morgan, 2016).

This last point alludes to the other key sources of inconsistency in the English care policy system (see Morgan, forthcoming, for further discussion). Firstly, decentralised governance structures, in particular policy domains, can contribute to even similar care relationship types experiencing divergent statutory support outputs on account of where they live and work. This is due to local authorities, Jobcentre Plus districts, and employer organisations being permitted significant levels of discretion within regulatory frameworks to determine how they discharge their statutory responsibilities. Consequently, informal carers could be treated inconsistently across JCP localities in relation to accessing and being charged for employability training courses. Furthermore, the legal framework permitted variations to exist across local authorities' eligibility policies, financial charging policies, and care service provision. The resulting territorial inequalities undermine informal care-related risks being treated as 
social risks by the state because the risks experienced by a care relationship may be socialised in one location but remain privatised in another. Secondly, the discretionary decision-making of practitioners could also significantly influence the level and types of statutory support and protection that care relationships can access. Not only was practitioner decision-making affected by their interpretation of the statutory regulations, but also by their personal attributes, experiences and attitudes. For example, one social work practitioner who was also an informal carer noted:

Because I am experiencing it myself ... I understand ... the strain that it puts you under ... I'm probably more likely to offer someone a carer's assessment than some of my colleagues.

In contrast a JCP practitioner took a more hard-line approach in their interactions with informal carers:

I mean I don't offer flexible support fund, I don't say do you need any [interview] clothes, no I'm sorry I don't, if they need them they need to tell me. I'm not going to guess.

Consequently the level of physical and emotional labour that practitioners were willing to invest in advocating on behalf of care relationships within institutional processes could significantly affect entitlement outcomes. Particularly as 'austerity-related' budget cuts were heightening the adversarial nature of resource allocation negotiations undertaken between managers and practitioners, who described these interactions using terms such as 'battles', 'fight' and 'argue' (Morgan, forthcoming).

\section{The production of secondary risks by state systems, policies and processes}

The care policy system itself, through the way in which it is constructed and policies are designed and operationalised, also produces secondary risks which can either create, maintain or exacerbate poverty and welfare risks for care relationships. For example, the complexity and fragmentation of the care policy system presents a significant barrier to care relationships accessing the statutory protection that is actually available. Figure 1 illustrates how the English care policy system is administered by various overarching government departments, with individual policy mechanisms being operationalised by a range of central and local government agencies including local authorities, Jobcentre Plus (JCP) and benefit agencies; and a multitude of external organisations including thirdsector agencies and employer organisations who either implement legislation, or are commissioned to provide statutory functions or support services.

This complexity can generate secondary risks in two ways: by leaving the recognised risks of risk-bearers unaddressed; and by creating additional financial or welfare risks. This is because the system requires informal carers to invest significant amounts of time and energy in finding out what statutory support 


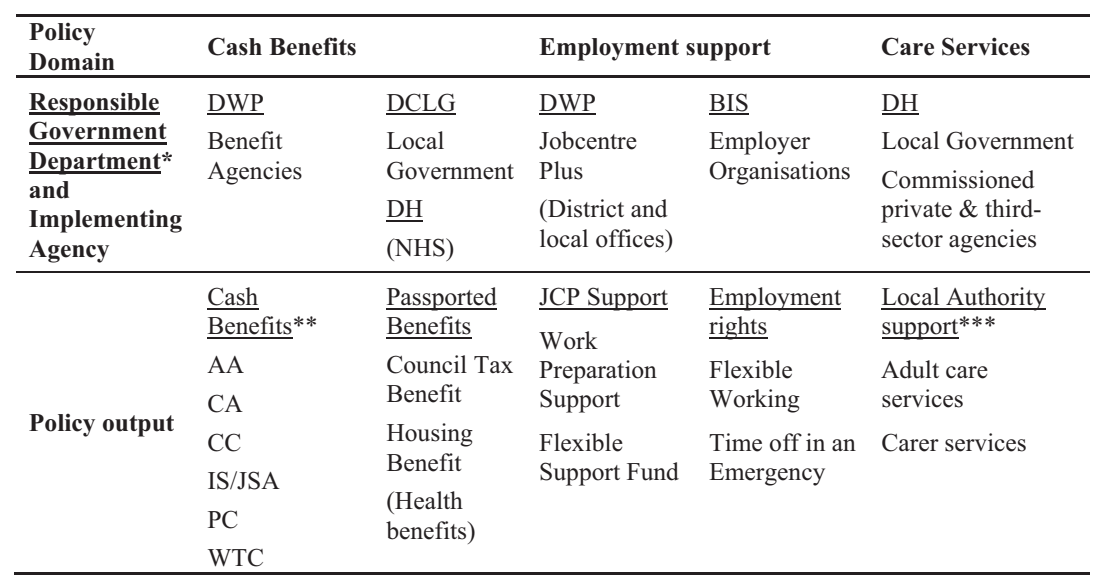

Notes:

* Department for Work and Pensions (DWP); Department for Communities and Local Government (DCLG); Department of Health (DH); Department for Business, Innovation and Skills (BIS).

** Attendance Allowance, Carer's Allowance, Carer's Credits, Income Support, Jobseeker's Allowance, Pension Credit, Working Tax Credit.

*** In the form of direct or commissioned service provision, or direct payments which individuals use to purchase their own services.

Figure 1: The English care policy system

is available and negotiating access to it via a potentially extensive range of agencies and practitioners. The siloed nature of each policy mechanism requires individuals to make separate applications via each institutional entry point, with the number of applications multiplying with each type of risk they face. Informal carers may also have to help the person they care for apply for their own support; indeed, the derived nature of some 'carer entitlements' may make this unavoidable (see Morgan, 2016). The variable eligibility criteria used across policy mechanisms, the opacity of policy regulations, and the unpredictability of discretionary decision-making, can generate considerable uncertainty for individuals who have no guarantee that their applications will be successful. The physical and emotional labour entailed in these endeavours are resources which, for informal carers, are often in short supply, particularly if their caring responsibilities continue unabated in the meantime. Furthermore, informal carers can face these secondary risks at multiple points in their care journey as the care relationship's needs and circumstances change.

Two further ways in which the English state produces secondary risks involve forms of risk-shifting. The first type of risk-shifting relates to the wider policy trend - the residualisation of welfare state support - which is increasingly forcing individuals to rely on market or family-based solutions to manage their social risks. The process of retrenching existing forms of social protection in the English 
care policy system has been accelerated under the Coalition and Conservative Governments' 'austerity' programmes, a key impact of which has been substantial local authority budget cuts (Lymbery, 2012). These cuts have contributed to local authorities attempting to shift the cost of care service provision away from the state in several ways: by referring individuals onto alternative sources of support, such as third-sector community services; and by resource allocation panels reducing the length and frequency of statutory support provided, which places obligations on families to provide, or continue to provide, care (Morgan, forthcoming).

If people were saying I can't do it anymore, it might be OK is that all the week, is that part of the week, are you still able to carry on doing weekends. (Local Authority Manager)

Consequently care-related risks which may previously have been addressed by the state are now more likely to remain fully or partially privatised.

The second type of risk-shifting state policies can engender is inter-relational risk-shifting. This occurs where policy mechanisms socialise the care-related risks of one risk-bearer whilst simultaneously generating or maintaining financial or welfare risks for the other. This can create dilemmas and conflicts for care relationships as they negotiate which member's needs and risks will be addressed (Morgan, forthcoming). For example, in the cash benefits domain the policy regulations, relating to Carer's Allowance and the Severe Disability Premium (SDP) for adults with disabilities, subject members of the caring dyad to mutually exclusive statutory entitlements. The SDP is purposively designed to support carereceivers with their care costs as long as no-one receives Carer's Allowance for looking after them. Consequently the caring dyad must decide which of them will not only forego some financial support but also the additional forms of statutory protection that their specific entitlement would bring: SDP increases a care-receiver's basic personal allowance amount which can extend access to means-tested and associated passported benefits; Carer's Allowance provides carers with National Insurance Contributions and protection from having to enter the labour market. Inter-relational risk shifting can also be caused by local authority charging policies for care services because these policies can have significant financial implications for care relationships, which may produce interrelational conflict, and maintain individuals' welfare risks. This was illustrated by a third-sector practitioner, who noted how one local authority's decision to categorise a carer break service as a chargeable service for the care-receiver, where previously it had been a free carer's service, had led older people to refuse support thereby leaving their informal carer unable to take a break from their caring role:

If a daughter wanted to go out on a regular basis ... now she has got to ask her father to add it to his package of care and pay an extra $\mathfrak{E}_{48} 8$ for 3 hours [sitting service] ... people have stopped having support because of that. 
Meanwhile charging informal carers for the services they receive ostensibly causes intra-personal risk-shifting. Informal carers must choose whether to address their current welfare risks by accepting support services and resign themselves to the extended poverty risks that this decision may incur in relation to their future financial security or vice versa.

\section{Conclusion}

The conceptualisation of social risk discussed in this paper identifies the key characteristics which support the categorisation of a contingency as a social risk, which is a state, rather than a private, responsibility to address. The additional distinction made between primary and secondary risks also helps to reveal how states, through their policy designs and interventions (which can include policy absences), may either address those risks, maintain existing risks, or create new risks, accordingly. This theoretical discussion helps to facilitate an understanding of the treatment of informal care-related risks by the English state. The empirical analysis reveals that the English state's intention to protect informal carers from the care-related risks they face, as purported by the national carer strategies and existing statutory provisions, is consistently undermined by the design of policies and processes, as well as system and practitioner effects. The primary poverty and welfare risks associated with informal care remain privatised to a greater or lesser extent, due to care-related risks and different care relationships types being subject to inadequate and inconsistent statutory recognition and protection. Moreover, secondary risks for care relationships are generated by the fragmented, opaque, unpredictable and adversarial care policy system and processes (see Morgan, forthcoming).

It is important to consider whether the major Care Act 2014 reform, implemented by the Coalition Government in 2015 in response to the institutional threats of population ageing (Lamb, 2014), has the potential to address some of the policy deficiencies identified in this paper. The Care Act 2014 has expanded, strengthened and attempted to standardise informal carers' rights in the care services domain. It has lowered the threshold for accessing a carer's assessment, which should ensure a universal entitlement is granted to informal carers with any level of need for support (Department of Health, 2016). Moreover, it introduced national eligibility criteria which, together with the new duty for local authorities to meet carers' eligible needs (HM Government, 2014), have the potential to reduce territorial inequalities in statutory support provision. However, the Act will not eradicate the inconsistent treatment of care relationships altogether. Charging policies, the types and level of services provided, and the implementation of more generous eligibility thresholds, remain the prerogative of each local authority to determine (Department of Health, 2016). Furthermore, this more progressive reform has occurred in the context of 
regressive policy trends which are simultaneously undermining carers' rights to statutory protection. The aforementioned severe cutbacks in central government funding for local authorities driven by successive Governments' neo-liberal 'austerity' measures have led to increased rationing of social care. Elsewhere, Government proposals to subsume Carer's Allowance into the new means-tested Universal Credit would restrict the already very limited financial protection provided by the state to the lowest income carers (Department for Work and Pensions, 2010).

A more fundamental reform of the overarching care policy system is required if informal care-related risks are to be treated as social risks by the English state. An unconditional basic income scheme (Standing, 2004; Van Parijs, 2004) could arguably offer universal financial protection to all informal carers (as long as a supplement was incorporated to address the additional care-related costs carers face), and eradicate the secondary risks associated with the complex benefit system. However, ultimately a system-wide restructure is required to ensure all care relationships are provided with comprehensive, consistent and adequate social protection to address their primary care-related risks and eliminate the secondary risks generated by the care policy system. This would require the following actions to be taken: align the eligibility criteria of all care policy mechanisms to provide parity of access to statutory protection; address policy absences and lower eligibility thresholds to widen access to statutory protection for all affected risk-bearers; provide equivalent support across localities; and design statutory support to address the specific care-related risks informal carers face and eliminate inter-relational risk-shifting. Lastly the English state must commit to adequately fund the care policy system.

\section{Acknowledgements}

This study is based on my $\mathrm{PhD}$ research undertaken at the University of Bath (2010-2015). I am very grateful for the support of my supervisors, Dr Emma Carmel and Professor Malcolm Johnson, and the University's scholarship programme which made completing my $\mathrm{PhD}$ possible. My thanks also extend to Graeme Simpson, University of Wolverhampton, and two anonymous reviewers of this article for their constructive comments and critique.

\section{Note}

1 The argument that social risks can exist prior to being recognised by states is open to debate. In this paper this argument is premised on a feminist interpretive policy analysis perspective (see Fraser, 1989 and Yanow, 1996).

2 Some managers only agreed to complete the interview schedule as a questionnaire.

\section{References}

Acas (2014), The right to request flexible working: an Acas guide. London: Acas Publications. Anttonen, A., Sipilä, J. and Baldock, J. (2003), Patterns of Social Care in Five Industrial Societies: Explaining Diversity, in A. Anttonen, J. Baldock, and J. Sipilä (eds.) The Young, the Old 
and the State. Social Care Systems in Five Industrial Nations. Cheltenham: Edward Elgar, pp. 167-197.

Baldwin, P. (1990), The Politics of Social Solidarity: Class Bases of the European Welfare State 1875-1975. Cambridge: Cambridge University Press.

Barnes, M. (2001), From private carer to public actor: The carers movement in England, in M. Daly (ed.) Care Work: The Quest for Security. London: International Labour Office, pp. 195-209.

Bonoli, G. (2007), Time Matters: Post-industrialisation, New Social Risks, and Welfare State Adaptation in Advanced Industrial Democracies. Comparative Political Studies, 40:5, 495520.

Bonoli, G. (2005), The politics of the new social policies: providing coverage against new social risks in mature welfare states. Policy \& Politics, 33:3, 431-449.

Bonoli, G. and Natali, D. (eds.) (2012), The Politics of the New Welfare State. Oxford: Open University Press.

Carers UK (2014), Caring and Family Finances Inquiry. UK Report. London: Carers UK.

Child Poverty Action Group (2012), Welfare benefits and tax credits handbook, 14th ed. London: Child Poverty Action Group.

Daly, M. and Rake, K. (2003), Gender and the Welfare State: Care, Work and Welfare in Europe and the USA. Cambridge: Polity Press.

Department for Work and Pensions (2016), Family Resources Survey 2014/15, https://www.gov. uk/government/uploads/system/uploads/attachment_data/file/531242/family-resourcessurvey-2014-15.pdf (accessed 27 November 2016).

Department for Work and Pensions (2010), Universal Credit: Welfare That Works, https://www. gov.uk/government/uploads/system/uploads/attachment_data/file/48897/universalcredit-full-document.pdf (accessed 27 November 2016).

Department of Health (2016), Care and Support Statutory Guidance. London: HMSO

Department of Health (2010), Recognised, valued and supported: Next steps for the Carers Strategy. London: HMSO.

Department of Health (2008), Carers at the heart of 21st century families and communities. London: HMSO.

Department of Health (1999), Caring about carers: a national strategy for carers. London: HMSO. Eardley, T. (1996), Lessons from a Study of Social Assistance Schemes in OECD countries, in L. Hantrais and S. Mangen (eds.), Cross National Research Methods in the Social Sciences. London: Pinter, pp. 51-62.

Ebbinghaus, B. (2012), Europe's Transformations Towards a Renewed Pension System, in G. Bonoli and D. Natali (eds.), The Politics of the New Welfare State. Oxford: Open University Press, pp. 182-205.

Esping-Andersen, G. (1999), Social Foundations of Post-Industrial Economies. Oxford: Oxford University Press.

Esping-Andersen, G., Gallie, D., Hemerijck, A. and Myles, J. (eds.), (2002), Why We Need a New Welfare State. Oxford: Oxford University Press.

Evandrou, M. and Glaser, K. (2003), Combining Work and Family Life: The Pension Penalty of Caring. Ageing \& Society, 23:5, 583-601.

Fraser, N. (1989), Unruly Practices: Power, Discourse and Gender in Contemporary Social Theory. Cambridge: Polity Press.

Glendinning, C., Tjadens, F., Arksey, H., Morée, M., Moran, N. and Nies, H. (2009), Care Provision within Families and its Socio-Economic Impact on Care Providers. University of York: Social Policy Research Unit.

Gov.uk (2016), Carer's Allowance, https://www.gov.uk/carers-allowance/what-youll-get (accessed 29 March 2016).

Gov.uk (2014), Flexible Working, https://www.gov.uk/flexible-working (accessed 30 July 2014).

Hacker, J.S. (2004), Privatizing Risk Without Privatizing the Welfare State: The Hidden Politics of Social Policy Retrenchment in the United States. American Political Science Review, 98:2, 243-260. 
HM Government (2014), Care Act 2014. London: HMSO.

HM Government (2011), Consultation on Modern Workplaces: Flexible working. London: HMSO.

HM Government (2006), Work and Families Act 2006. London: HMSO.

HM Government (2004), Carers (Equal Opportunities) Act 2004. London: HMSO.

HM Government (1999), Employment Relations Act 1999. London: HMSO.

HM Government (1995), Carers (Recognition and Services) Act 1995, London: HMSO.

Huber, E. and Stephens, J.D. (2006), Combating old and new social risks, in K. Armingeon and G. Bonoli (eds.), The Politics of Post-Industrial Welfare States: Adapting Post-War Social Policies to New Social Risks. Abingdon: Routledge, pp. 143-168.

Jenson, J. (1997), Who Cares? Gender and Welfare Regimes. Social Politics: International Studies in Gender, State \& Society, 4:2, 182-187.

Kananen, J., Taylor-Gooby, P. and Larsen, T.P. (2006), Public attitudes and new social risks, in K. Armingeon and G. Bonoli (eds.), The Politics of Post-Industrial Welfare States: Adapting Post- War Social Policies to New Social Risks. Abingdon: Routledge, pp. 83-99.

King, D. and Pickard, L. (2013), When is a carer's employment at risk? Longitudinal analysis of unpaid care and employment in midlife in England. Health \& Social Care in the Community, 21:3, 303-314.

Kitschelt, H. and Rehm, P. (2006), New social risks and political preferences, in K. Armingeon and G. Bonoli (eds.), The Politics of Post-Industrial Welfare States: Adapting Post-War Social Policies to New Social Risks. Abingdon: Routledge, pp. 52-82.

Kok, R., Avendano, M. and Mackenbach, J. (2008), The Association Between Socioeconomic Status and Changes in Health In Europe, in A. Börsch-Supan, A. Brugiavini, H. Jürges, A. Kapteyn, J. Mackenbach, J. Siegrist and G. Weber (eds.), First Results from the Survey of Health, Ageing and Retirement in Europe (2004-2007). Starting the Longitudinal Dimension. Mannheim: Mannheim Research Institute for the Economics of Aging (MEA), pp. 125-130.

Lamb, N. (2014), Care Bill becomes Care Act 2014, https://www.gov.uk/government/speeches/ care-bill-becomes-care-act-2014 (accessed 30 July 2014).

Larkin, M. and Milne, A. (2014), Carers and Empowerment in the UK: A Critical Reflection. Social Policy and Society, 13:1, 25-38.

Lloyd, L. (2006), Call us carers: Limitations and risks in campaigning for recognition and exclusivity. Critical Social Policy, 26:4, 945-960.

Lymbery, M. (2012), Social Work and Personalisation. British Journal of Social Work, 42:4, 783-792.

Milne, A., Brigden, C., Palmer, A. and Konta, E. (2013), The intersection of employment and care: evidence from a UK case study. European Journal of Social Work, 16:5, 651-670.

Morel, N. (2006), Providing coverage against new social risks in Bismarkian welfare states, in K. Armingeon and G. Bonoli (eds.), The Politics of Post-Industrial Welfare States: Adapting Post-War Social Policies to New Social Risks. Abingdon: Routledge, pp. 227-247.

Morgan, F. (2016), The treatment of informal care as a social risk in England: Conceptual and methodological innovations in undertaking comparative care policy analysis. ESPAnet Annual Conference, Re-inventing the Welfare State? Pathways to sustainability, equality and inclusion in European welfare states, 1-3 September, Rotterdam, Netherlands.

Morgan, F. (forthcoming), Understanding the complexity and implications of the English care policy system: a governance analysis approach, in E. Carmel (ed.), Governance analysis: critical enquiry at the intersection of society, politics and public policy. Cheltenham: Edward Elgar.

Office for National Statistics (2016), Population estimates by single year of age and sex for local authorities in the UK, mid-2015, https://www.ons.gov.uk/ peoplepopulationandcommunity/populationandmigration/populationestimates/ datasets/populationestimatesforukenglandandwalesscotlandandnorthernireland (accessed 24 February 2017). 
Office for National Statistics (2014a), Females live longer than males but spend a larger proportion of their lives with a disability, http://www.ons.gov.uk/ons/rel/census/2011census-analysis/disability-free-life-expectancy-at-birth-at-age-50-and-at-age-65-clinicalcommissioning-groups-ccgs-2010-12/sty-disability-free-life-expectancy.html (accessed 20 October 2014).

Office for National Statistics (2014b), Unpaid Care Expectancies across NHS Clinical Commissioning Groups, England 2010-12, http://www.ons.gov.uk/ons/dcp171776_366321.pdf (accessed 26 April 2015).

Office for National Statistics (2013a), 2011 Census: Key Statistics and Quick Statistics for local authorities in the United Kingdom. Provision of unpaid care, local authorities in the United Kingdom, http://www.ons.gov.uk/ons/taxonomy/search/index .$h t m l$ ?nscl=Carers\&nscl-orig $=$ Carers\&content-type $=$ Dataset\&content-type $=$ Reference + table\&sortDirection=DESCENDING\&sortBy=pubdate (accessed 19 April 2014).

Office for National Statistics (2013b), Inequality in the provision of unpaid care in England and Wales, http://www.ons.gov.uk/ons/rel/census/2011-census/detailed-characteristicsfor-local-authorities-in-england-and-wales/sty-unpaid-care.html (accessed 20 October 2014).

Pavolini, E. and Ranci, C. (2008), Restructuring the welfare state: reforms in long-term care in Western European countries. Journal of European Social Policy, 18:3, 246-259.

Pickard, L., Wittenberg, R., Comas-Herrera, A., King, D. and Malley, J. (2012), Mapping the future of family care: receipt of informal care by older people with disabilities in England to 2032. Social Policy and Society, 11:4, 533-545.

Singleton, B.E. and Fry, G. (2015), Citizen Carer: Carer's Allowance and Conceptualisations of UK Citizenship. Journal of Social Policy, 44:3, 549-566.

Standing, G. (2004), About Time: Basic Income Security as a Right, in G. Standing (ed.), Promoting Income Security as a Right: Europe and North America. London: Anthem Press, pp. 1-39.

Taylor-Gooby, P. (ed.), (2004a), New Risks, New Welfare: The Transformation of the European Welfare State. Oxford: Oxford University Press.

The NHS Information Centre (2010), Survey of Carers in Households 2009/10. Leeds: The Health and Social Care Information Centre.

Timonen, V. (2004), New Risks - Are They Still New for the Nordic Welfare States?, in P. TaylorGooby (ed.), New Risks, New Welfare: The Transformation of the European Welfare State. Oxford: Oxford University Press, pp. 83-110.

Tommis, Y., Robinson, C.A., Seddon, D., Woods, B., Perry, J. and Russell, I.T. (2009), Carers with chronic conditions: Changes over time in their physical health. Chronic Illness, 5:3, 155-164.

Van Parijs, P. (2004), Basic Income: A Simple and Powerful Idea for the Twenty-First Century. Politics and Society, 32:1, 7-39.

Vlachantoni, A., Evandrou, M., Falkingham, J. and Robards, J. (2013), Informal care, health and mortality. Maturitas, 74:2, 114-118.

Yanow, D. (1996), How Does a Policy Mean? Interpreting Policy and Organizational Actions, Washington, D.C.: Georgetown University Press. 